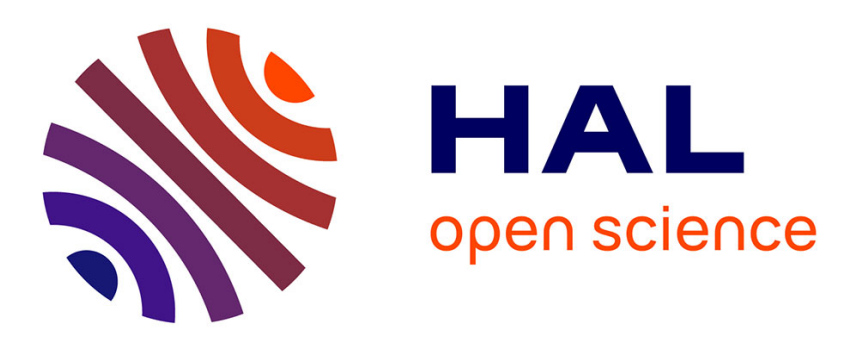

\title{
Somatic embryogenesis in cotyledons of Picea abies is enhanced by and adventitious bud-inducing treatment
}

\author{
Marie-Anne Lelu-Walter, Michel P. Boulay, Chris H. Bornman
}

\section{To cite this version:}

Marie-Anne Lelu-Walter, Michel P. Boulay, Chris H. Bornman. Somatic embryogenesis in cotyledons of Picea abies is enhanced by and adventitious bud-inducing treatment. New Forests, 1990, 4 (2), pp.125-135. 10.1007/BF00119005 . hal-02711858

\section{HAL Id: hal-02711858 \\ https://hal.inrae.fr/hal-02711858}

Submitted on 1 Jun 2020

HAL is a multi-disciplinary open access archive for the deposit and dissemination of scientific research documents, whether they are published or not. The documents may come from teaching and research institutions in France or abroad, or from public or private research centers.
L'archive ouverte pluridisciplinaire HAL, est destinée au dépôt et à la diffusion de documents scientifiques de niveau recherche, publiés ou non, émanant des établissements d'enseignement et de recherche français ou étrangers, des laboratoires publics ou privés. 


\title{
Somatic embryogenesis in cotyledons of Picea abies is enhanced by an adventitious bud-inducing treatment
}

\author{
MARIE-ANNE P. LELU ${ }^{1,2}$, MICHEL P. BOULAY ${ }^{3}$ and \\ CHRIS H. BORNMAN ${ }^{1}$ \\ 1 Research Division, Hilleshög AB, Box 302, S-26123 Landskrona, Sweden; ( ${ }^{2}$ present \\ address: INRA, Centre de Recherches d'Orleans, Ardon, F-45160 Olivet, France); ${ }^{3}$ LVMH \\ Recherche Groupe Louis Vuitton-Moet-Hennessy, 50 rue de Seine, F-92704 Colombes, \\ France
}

Received 7 November 1989; accepted 11 June 1990

Key words: Norway spruce, tissue culture

Application. Somatic embryogenesis in the Coniferales is regarded as a potential tool in the micropropagation of forest trees. This study reports on somatic embryogeny in Picea abies, induced in excised cotyledons. It represents a possible basis for the establishment of the technology that will be required to manipulate tissues of superior trees.

Abstract. Somatic embryos were obtained from young, isolated cotyledons of Picea abies. A bud-inductive treatment for one week before transfer to a callus induction medium, resulted in a tenfold increase in the percentage of cotyledons in which embryonic tissues could be induced. The degree of expression of somatic embryogeny depends on whether cotyledons are first subjected to a callus-inducing medium or first exposed to a cytokinin treatment followed by a callus-inducing medium. It is hypothesized that two populations of cells exist, both with the inherent potential of becoming embryogenic after treatment with plant growth regulators.

\section{Introduction}

Somatic embryogenesis, first reported in Picea abies (L. Karst.) by Hakman et al. (1985), has since been induced in several coniferous species (Table 1). Until now, the tissue source has been either immature zygotic embryos or mature zygotic embryos prior to germination. However, more recently embryogenesis was obtained also from cotyledons excised from newly-germinated seeds of Picea abies (Lelu et al. 1987).

In attempting to induce embryogenesis most conifer experimentalists hitherto have subjected their explants to conditions that promote callogenesis. However, Krogstrup (1986) first pretreated them for 3 weeks with 


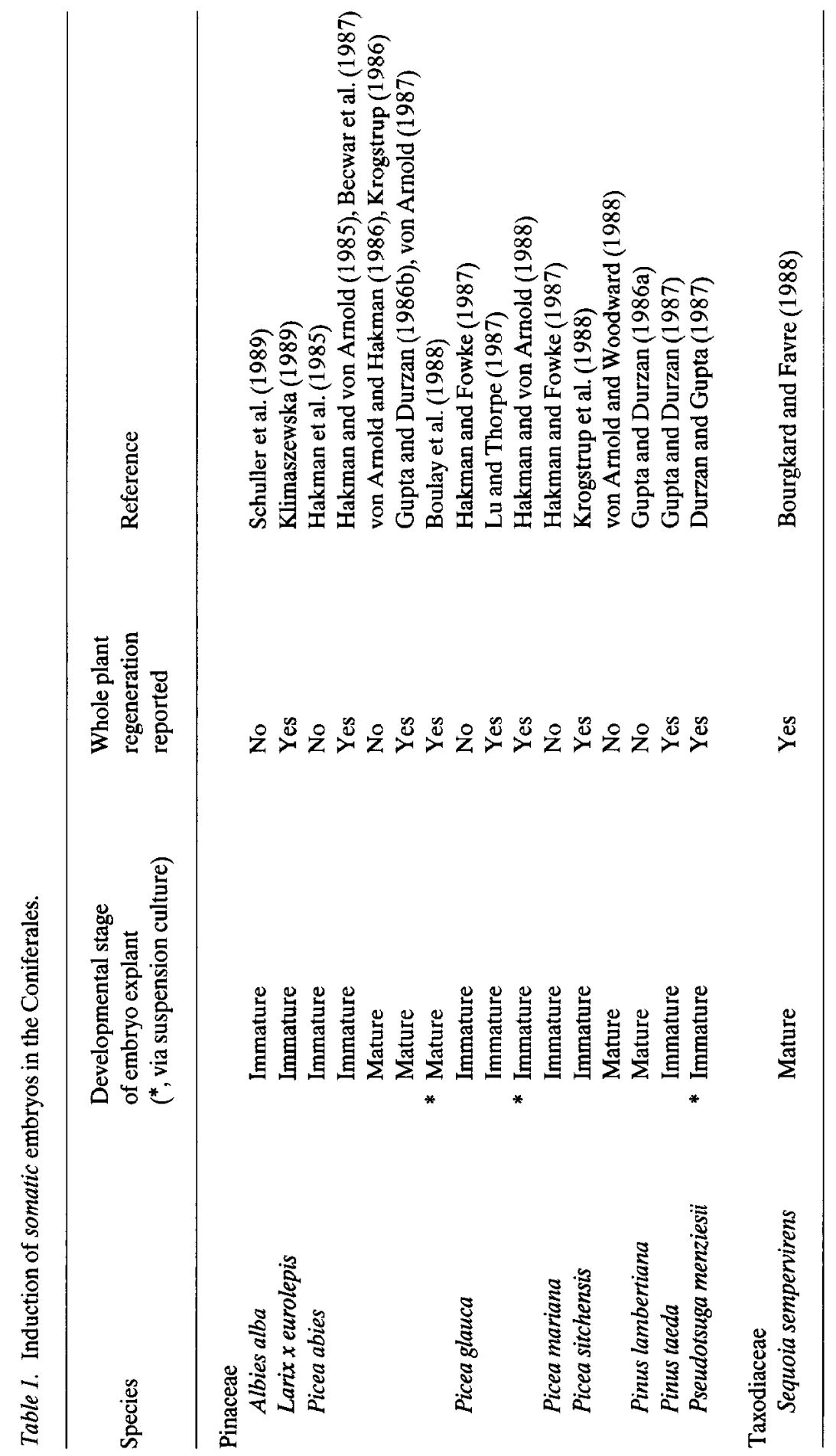


benzyladenine (BA) and Lelu et al. (1987) observed that pre-culturing on an adventitious bud-induction medium promoted subsequent embryogenesis. The goals of this study were to:

- use napthaleneacetic acid (NAA) rather than 2,4-dichlorophenoxyacetic acid (2,4-D) (Lelu et al. 1987),

- reconfirm the prior observation of the beneficial effect of an adventitious bud-inducing medium containing NAA on somatic embryogenesis, and

- develop a better understanding of the process of embryo induction.

\section{Material and methods}

\section{Seed}

Seeds of Picea abies were collected in 1984-1985 from trees in the Gerardmer area of France. They were stored at $4{ }^{\circ} \mathrm{C}$ in darkness for 2 years. After immersion in a surfactant $(1 \% \mathrm{v} / \mathrm{v}$ Teepol), the seeds were surface-sterilized in $15 \%(\mathrm{v} / \mathrm{v}) \mathrm{H}_{2} \mathrm{O}_{2}$ for $10 \mathrm{~min}$ and rinsed twice in sterile distilled water. The seeds were planted in sterile, moist vermiculite and germinated aseptically at $25 / 20^{\circ} \mathrm{C} \pm 1{ }^{\circ} \mathrm{C}$ in a $16 / 8 \mathrm{~h}$ day/night. After one week, the radicles emerged and 3 to 5 days later the 2- to 5 -mm-long cotyledons were excised. It had been determined earlier (Lelu et al. 1987) that a length of $2-5 \mathrm{~mm}$ was optimal for the induction of somatic embryogenesis.

\section{Culture media and culture conditions}

Table 2 summarizes the culture media and conditions used. All cultures were incubated in $90-\mathrm{mm}$ diameter petri dishes containing $20 \mathrm{ml}$ medium; $\mathrm{pH}$ of the medium was adjusted to $5.8 \pm 0.1$ prior to sterilization by autoclaving at $100 \mathrm{kPa}$ and $120^{\circ} \mathrm{C}$ for $20 \mathrm{~min}$. Where used, light was applied at a photon flux density of $70 \mu \mathrm{mol} \mathrm{m}^{-2} \mathrm{~s}^{-1}$ supplied by $40 \mathrm{~W}$ fluorescent lamps (Sylvania Grolux). Whole excised cotyledons were cultured on bud-induction medium (Table 2) for 1, 2 or 3 weeks. After this treatment, half the number of cotyledons were transferred to a buddevelopment medium (Table 2) and well-formed buds were scored 2 months later (since other neoformations were also visible, Bornman 1987). The remaining cotyledons were cut into $2 \mathrm{~mm}$ explants, which were placed on callus-induction medium (Table 2). As control, pieces of excised cotyledons were also placed directly on callus-induction medium. 
Table 2. Culture media and culture conditions.

\begin{tabular}{|c|c|c|c|}
\hline \multirow{2}{*}{$\begin{array}{l}\text { Constituents } \\
\text { and conditions }\end{array}$} & \multicolumn{3}{|l|}{ Media for } \\
\hline & Bud induction & Bud development & Callus induction \\
\hline Macronutrients elements & $\mathrm{CD}$ & $\begin{array}{l}\mathrm{CD} \\
\text { (half-strength) }\end{array}$ & MS \\
\hline Micronutrients elements & $\begin{array}{l}\text { MS } \\
\text { (half-strength) }\end{array}$ & $\begin{array}{l}\text { MS } \\
\text { (half-strength) }\end{array}$ & MS \\
\hline Sucrose, mM & 90 & 45 & 90 \\
\hline Myoinositol, mM & 2.7 & 0.55 & 0.55 \\
\hline Thiamine. $\mathrm{HCl}, \mu \mathrm{M}$ & 15 & 1.2 & 30 \\
\hline $\begin{array}{l}\mathrm{BA}, \mu \mathrm{M} \\
\mathrm{NAA}, \mu \mathrm{M}\end{array}$ & $\begin{array}{l}4.5 \\
0.05\end{array}$ & $\begin{array}{l}0 \\
0\end{array}$ & $\begin{array}{l}0 \text { or } 0.45 \\
5.4 \text { or } 10.7\end{array}$ \\
\hline $\begin{array}{l}\text { Agar (Bacto-Difco), } \text { gl }^{-1} \\
\text { Light (photoperiod, } h \text { ) } \\
\text { Temperature, }{ }^{\circ} \mathrm{C} \pm 1\end{array}$ & $\begin{array}{l}8 \\
\text { continuous } \\
20\end{array}$ & $\begin{array}{l}8 \\
16 / 8 \\
25 / 20\end{array}$ & $\begin{array}{l}8 \\
\text { darkness } \\
25\end{array}$ \\
\hline
\end{tabular}

CD, Campbell and Durzan (1975); MS, Murashige and Skoog (1962).

The presence of embryogenic callus was determined after 4 weeks on the latter medium by cytological examination.

\section{Cytological and histological examination}

For callus, squashes were prepared in aceto-orcein (Lacour 1941) as this dye neither stains the cytoplasm or nucleoli, nor overstains the chromosomes. Callus was considered as embryogenic when multiple embryonal segments and masses of cells as well as suspensor-like cells could be identified. Morphogenesis of the cotyledon during the culture phases on bud- and callus-induction media was followed by examining $2 \mu \mathrm{m}$-thick sections of glutaraldehyde-fixed and glycol methacrylate-embedded tissue stained with toluidine blue and basic fuchsin (Feder and O'Brien 1968).

\section{Results and discussion}

When subjected directly to callus induction without a bud-induction pretreatment, some cotyledons developed embryogenic callus after 4 weeks. The embryogenic nature of the culture was confirmed cytologically and found to correspond with the observations made previously in respect of $P$. abies by Hakman et al. (1985), Gupta and Durzan (1987), and Lelu 
et al. (1987). Table 3 shows that using only callus-induction medium, the percentage of plated seedling cotyledons that developed embryogenic callus was low, approximately $2 \%$. By comparison, Hakman and von Arnold (1985) reported a 50\% yield in embryogenic callus from immature embryos and von Arnold (1987) a similar frequency from mature zygotic embryos. We believe this difference may be accounted for by explant age, that is loss of juvenility.

However, when we applied a bud-inducing treatment prior to the transfer of the explants to the callogenic medium, the response varied according to the duration of the culture on the bud-inducing medium, but a one-week exposure to the highest auxin concentration $(10.7 \mu \mathrm{M}$ NAA in combination with $0.45 \mu \mathrm{M} \mathrm{BA}$ ) resulted in an increase from 2 to $20 \%$ of cotyledons with embryogenic callus. The concentrations of the plant growth regulators used in the callus-inducing medium (Table 2) were actually lower than and the combinations different from those previously used, i.e. 2,4-D 9.05/BA 4.5 $\mu \mathrm{M}$ or NAA 21.5/BA $0.45 \mu \mathrm{M}$ (Lelu et al. 1987). Somatic embryogenesis from excised cotyledons of Picea abies was also induced with auxin alone (NAA $5.4 \mu \mathrm{M}$ ), an observation that differs

Table 3. Effect of duration of bud induction treatment on formation of embryogenic callus from excised cotyledons of Picea abies (2-5 mm length) subjected to different callus induction treatments. The data, obtained after 4 weeks on callus induction medium, were pooled from 3 separate experiments.

\begin{tabular}{|c|c|c|c|c|}
\hline \multirow[t]{2}{*}{$\begin{array}{l}\text { Bud induction } \\
\text { pretreatment } \\
\text { (BA 4.5, } \\
\text { NAA 0.05 } \mu \mathrm{M} \text { ) } \\
\quad \text { Week }\end{array}$} & \multicolumn{2}{|c|}{$\begin{array}{l}\text { Callus induction } \\
\text { treatment: } \\
\text { concentration } \\
\text { of plant growth } \\
\text { regulators, } \mu \mathrm{M}\end{array}$} & \multirow[t]{2}{*}{$\begin{array}{l}\text { Number } \\
\text { cotyledons } \\
\text { cultured }\end{array}$} & \multirow[t]{2}{*}{$\begin{array}{l}\text { No. cotyledons } \\
\text { with embryogenic } \\
\text { callus per } \\
100 \text { plated } \\
\text { cotyledons }\end{array}$} \\
\hline & $\mathrm{BA}$ & NAA & & \\
\hline & 0 & 5.4 & 112 & 2.6 \\
\hline 0 & $\begin{array}{l}0.45 \\
0.45\end{array}$ & $\begin{array}{r}5.4 \\
10.7\end{array}$ & $\begin{array}{l}118 \\
128\end{array}$ & $\begin{array}{l}2.5 \\
2.3\end{array}$ \\
\hline 1 & $\begin{array}{l}0 \\
0.45 \\
0.45\end{array}$ & $\begin{array}{r}5.4 \\
5.4 \\
10.7\end{array}$ & $\begin{array}{l}102 \\
111 \\
103\end{array}$ & $\begin{array}{r}8.0 \\
2.0 \\
20.3\end{array}$ \\
\hline 2 & $\begin{array}{l}0 \\
0.45 \\
0.45\end{array}$ & $\begin{array}{r}5.4 \\
5.4 \\
10.7\end{array}$ & $\begin{array}{l}107 \\
101 \\
111\end{array}$ & $\begin{array}{r}10.3 \\
2.0 \\
3.6\end{array}$ \\
\hline 3 & $\begin{array}{l}0 \\
0.45 \\
0.45\end{array}$ & $\begin{array}{r}5.4 \\
5.4 \\
10.7\end{array}$ & $\begin{array}{l}109 \\
110 \\
101\end{array}$ & $\begin{array}{l}0 \\
4.5 \\
3\end{array}$ \\
\hline
\end{tabular}


from that of von Arnold (1987) who found that the obtention of embryogenic callus from mature zygotic embryos of Picea abies was both auxinand cytokinin-dependent.

Increasing the duration on the bud-inducing medium beyond one week decreased the embryogenic response (Table 3). The small increase from 2 to $4.5 \%$ observed with NAA $(5.4 \mu \mathrm{M})$ and BA $(0.45 \mu \mathrm{M})$ after a 3-week exposure could be considered as experimental variation.

With bud-inducing treatment, in addition to the embryogenic and nonembryogenic calli, newly-formed adventitious, meristematic and foliar structures occurred on the cotyledon's surface (Fig. 1) and in the dark most of these subsequently developed into etiolated buds on the callusinduction medium. The total number of cotyledons responding to the budinduction treatment did not increase markedly between weeks 2 and 3, but the number of adventitious buds doubled over the same period (Table 4), a phenomenon also observed previously (Bornman and Jansson 1981; Bornman 1983). With exposure to bud-induction treatment, in contrast to induction of embryogenic callus, the number of reacting explants doubled between weeks 1 and 2 and slightly later (43-83-89\% for weeks 1-2-3, respectively, Table 4 ), whereas the number of newly-formed adventitious buds continued to increase (87-319-627 for weeks 1-2-3, respectively).

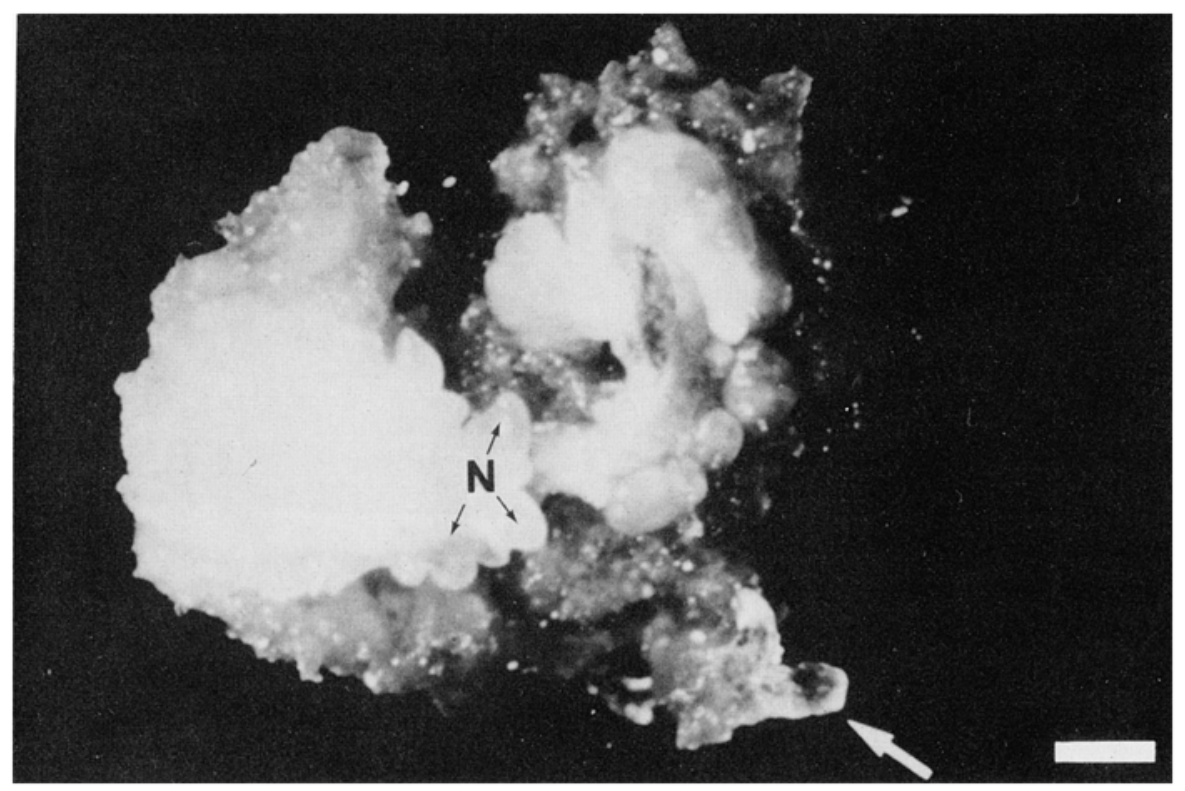

Fig. 1. Cotyledon of Picea abies exposed to a one-week bud-inducing treatment followed by 4 weeks on a callus-inducing medium. Embryogenic callus (arrow) and neoformed adventitious structures $(\mathrm{N})$ can be distinguished. Bar represents $1 \mathrm{~mm}$. 
Table 4. Effect of duration of bud induction treatment on formation of adventitious buds from excised cotyledons of Picea abies ( $2-5 \mathrm{~mm}$ length). The data, obtained after 8 weeks in culture on bud development medium, were pooled from 2 separate experiments.

\begin{tabular}{|c|c|c|c|}
\hline $\begin{array}{l}\text { Bud induction } \\
\text { pretreatment } \\
\text { (BA 4.5, } \\
\text { N } \Lambda \text { } 4.05 \mu \mathrm{M} \text { ) } \\
\quad \text { Week }\end{array}$ & $\begin{array}{l}\text { No. cotyledons } \\
\text { cultured }\end{array}$ & $\begin{array}{l}\text { Per cent } \\
\text { cotyledons with } \\
\text { adventitious buds, } \\
\%\end{array}$ & $\begin{array}{l}\text { No. adventitious } \\
\text { buds per } 100 \\
\text { plated cotyledons }\end{array}$ \\
\hline 0 & 111 & 0 & 0 \\
\hline 1 & 76 & 43 & 87 \\
\hline 2 & 87 & 83 & 319 \\
\hline 3 & 66 & 89 & 627 \\
\hline
\end{tabular}

Histological examination of cotyledons of Picea abies showed that the conditions for callusing led to an enlargement of especially the mesophyll cells (Fig. 2), resulting in the subsequent disorganization of the tissues they comprised in relation to form and orientation. This was in marked contrast to the bud-inducing treatment, which resulted in the differentiation of

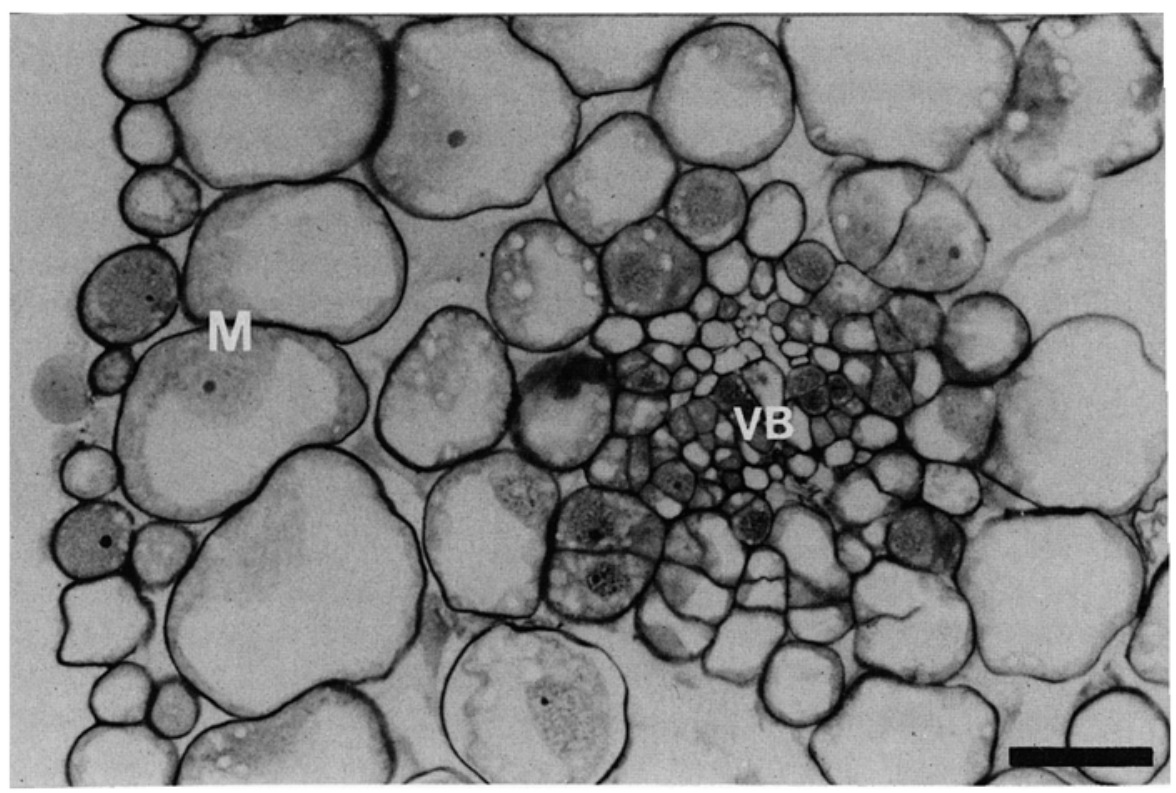

Fig. 2. Transverse section of midpart of cotyledon subjected for one week to callusinducing medium only. As compared to the initial tissue, cells of the mesophyll (M) are hypertrophied and, except for the parenchyma associated with the vascular bundle (VB), show virtually no meristematic activity. Bar represents $50 \mu \mathrm{m}$. 
promeristemoids in epidermal and sub-epidermal cells after 1 week (Fig. 3 ), the reactivity becoming very pronounced when a 3-week treatment was applied (Lelu et al. 1987). Sub-epidermal layers have been demonstrated to be active in the formation of adventitious buds in isolated cotyledonary explants of various coniferous species (Yeung et al. 1981; Jansson and Bornman 1981; Bornman 1983; Villalobos et al. 1985; Flinn et al. 1988).

After 3 weeks in callogenesis, the presence of somatic proembryos were found to have originated from cells of the epidermis and subepidermis (Fig. 4).

The results obtained in our study lead us to hypothesize the existence of two cell populations. One cell population could be triggered directly by auxin only, or by a high ratio of auxin to cytokinin (NAA:BA $=12: 1$ or 24:1), giving rise to embryogenic cultures (such as those in Table 3 corresponding to $2 \%$ of the cotyledons that reacted directly to the callus induction treatment). The other cell population responds more efficiently to auxin treatment when first pretreated with cytokinin. The highest percentage of embryogenic cultures were obtained after 1 week on a budinduction medium in which the ratio of cytokinin to auxin was 90:1. In this

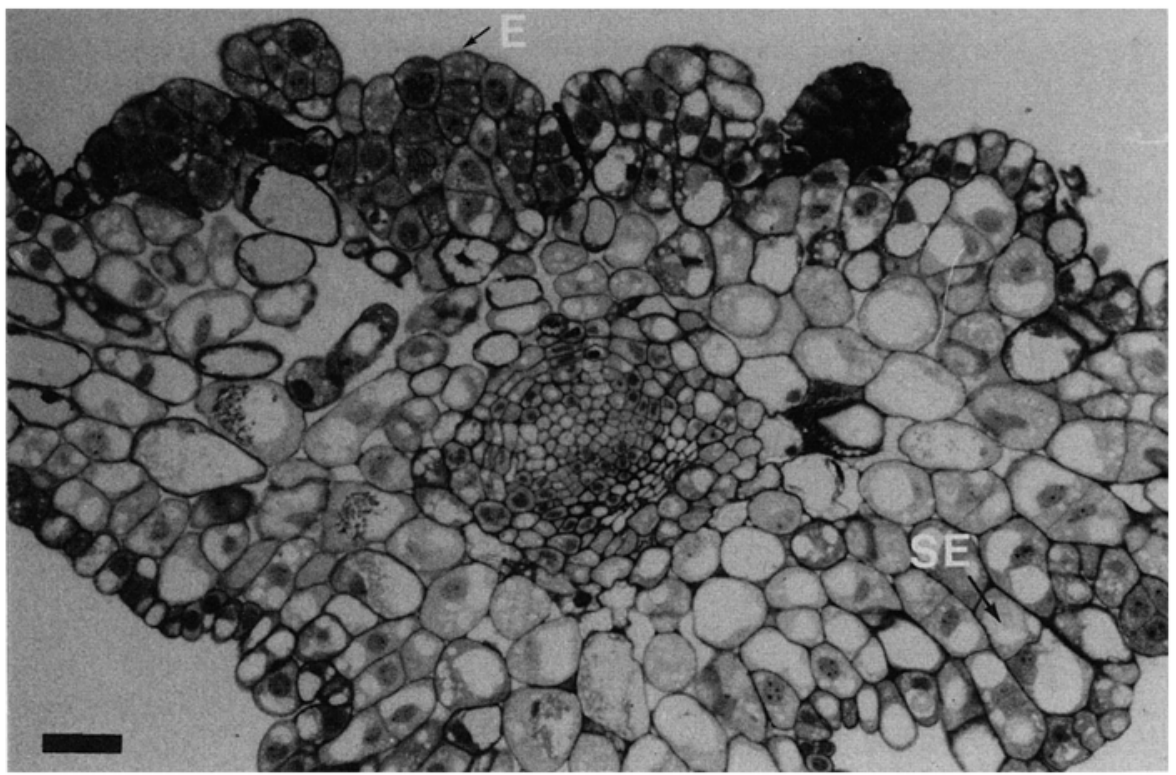

Fig. 3. Transverse section of midpart of cotyledon exposed to callus-inducing medium for one week, but pretreated for one week on a bud-inducing medium. In addition to cell divisions in the mesophyll, extensive meristematic activity can be observed in epidermal (E) and sub-epidermal (SE) cell layers, as well as in the parenchyma of the vascular bundle. Bar represents $50 \mu \mathrm{m}$. 


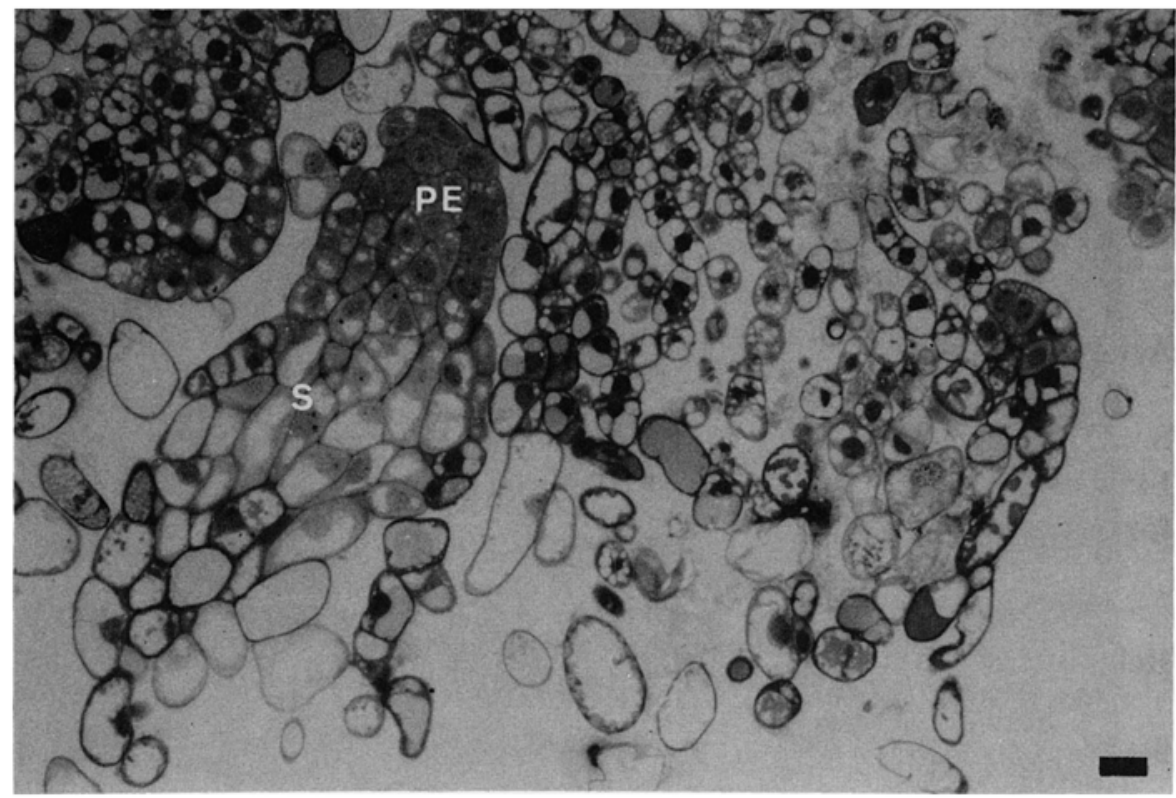

Fig. 4. Longitudinal section of midpart of cotyledon exposed to a one-week bud-inducing treatment followed by 3 weeks on a callus-inducing medium. Developing and well-developed somatic pro-embryos are now presented. Somatic proembryos are characterized by proembryonal (PE) and suspensorial (S) parts. Bar represents $50 \mu \mathrm{m}$.

case, the duration of the cytokinin treatment appears to be critical for the dedifferentiation of epidermal and sub-epidermal cells into either embryogenic precursor cells (treatment of relatively short duration, 1 week) or into adventitious buds (treatment of relatively long duration, $2-3$ weeks).

Embryogenic calli thus obtained can be multiplied using the medium described by Gupta and Durzan (1986b). Entire spruce plants have also been regenerated.

\section{Conclusion}

In our experiments, a cytokinin bud-induction pretreatment has been useful in increasing the embryogenic capacity of isolated cotyledons of $P$. abies. Krogstrup (1986) pretreated his explants with BA, but gave no evidence of its beneficial effect and was unable to obtain regeneration of whole plants. There is a further interest in using the system described here, namely its possible application to tissues of mature trees. Vegetative dormant buds and needles and even needle primordia, have been shown to react in a manner similar to cotyledons as far as adventitious bud 
induction is concerned (Jansson and Bornman 1983; von Arnold and Eriksson 1979a, b). Such buds are now being used as primary explants for induction of embryogenic cultures from young and maturing trees. The first experiments using such dormant and flushing buds have shown interesting morphological responses.

\section{Acknowledgements}

Some experiments were conducted in the laboratory of AFOCEL, Nangis, France. We express our thanks to Messrs G. Touzet and D. X. Destremau for their support of this study.

\section{References}

Becwar, M. R., Verhagen, S. A. and Wann, S. R. 1987. The frequency of plant regeneration from Norway spruce somatic embryos, pp. 92-100. In: Proc. 19 Southern Forest Tree Improvement Conference June 16-18 college station TX.

Bornman, C. H. 1983. Possibilities and constraints in the regeneration of trees from cotyledonary needles of Picea abies in vitro. Physiol. Plant. 57: 5-16.

- 1987. Picea abies, pp. 2-29. In: Bonga, J. M. and Durzan, D. J. (Eds) Cell and Tissue in Forestry, Vol. III. Martinus Nijhoff/Dr. W. Junk Publs., Dordrecht.

Bornman, C. H. and Jansson, E. 1981. Regeneration of plants from the conifer leaf with special reference to Picea abies and Pinus sylvestris, pp. 41-53. In: Colloque International sur la Culture "in vitro" des Essences Forestières. IUFRO, Fontainebleau, France, IUFRO/AFOCEL.

Boulay, M. P., Gupta, P. K., Krogstrup, P. and Durzan, D. J. 1988. Development of somatic embryos from cell suspension cultures of Norway spruce. Plant Cell Reports 7: 134137.

Bourgkard, F. and Favre, J. M. 1988. Somatic embryos from callus of Sequoia sempervirens. Plant Cell Reports 7: 445-448.

Campbell, R. A. and Durzan, D. J. 1975. Induction of multiple buds and needles in tissue cultures of Picea glauca. Can. J. Bot. 53: 1652-1657.

Durzan, D. J. and Gupta, P. K. 1987. Somatic embryogenesis and polyembryogenesis in Douglas-fir cell suspension cultures. Plant Sci. 52: 229-235.

Feder, N. and O’Brien, T. P. 1968. Plant microtechnique: some principles and new methods. Amer. J. Bot. 55: 123-142.

Flinn, B. S., Webb, D. T. and Newcomb, W. 1988. The role of cell clusters and promeristemoids in determination and competence for caulogenesis by Pinus strobus cotyledons in vitro. Can. J. Bot. 66: 1556-1565.

Gupta, P. K. and Durzan, D. J. 1986a. Somatic polyembryogenesis from callus of mature sugar pine embryos. Bio/Technology 4: 643-645.

- 1986b. Plantlet regeneration via somatic embryogenesis from subcultured callus of mature embryos of Picea abies (Norway spruce). In Vitro Ceil Development Biol. 22: $685-688$.

- 1987. Biotechnology of somatic polyembryogenesis and plantlet regeneration in loblolly pine. Bio/Technology 5: 147-151. 
Hakman, I. and Fowke, L. C. 1987. Somatic embryogenesis in Picea glauca (white spruce) and Picea mariana (black spruce). Can. J. Bot. 65: 656-659.

Hakman, I. and von Arnold, S. 1985. Plantlet regeneration through somatic embryogenesis in Picea abies (Norway spruce). J. Plant Physiol. 121: 149-158.

- 1988. Somatic embryogenesis and plant regeneration from suspension cultures of Picea glauca (white spruce). Physiol. Plant. 72: 579-587.

Hakman, I., Fowke, L. C., von Arnold, S. and Eriksson, T. 1985. The development of somatic embryos in tissue cultures initiated from immature embryos of Picea abies (Norway spruce). Plant. Sci. 38: 53-59.

Jansson, E. and Bornman, C. H. 1981. In vitro initiation of adventitious structures in relation to the abscission zone in needle explants of Picea abies: anatomical consideration. Physiol. Plant. 53: 191-197.

- 1983. Morphogenesis in dormant embryonic shoots of Picea abies: influence of the crown and cold treatment. Physiol. Plant. 59: 1-8.

Klimaszewska, K. 1989. Plantlet development from immature zygotique embryos of hybrid larch through somatic embryogenesis. Plant Science 63: 95-103.

Krogstrup, P. 1986. Embryo-like structures from cotyledons and ripe embryos of Norway spruce. Can. J. For. Res. 16: 664-668.

Krogstrup, P., Eriksen, E. N., Moller, J. D. and Roulund, H. 1988. Somatic embryogenesis in sitka spruce (Picea sitchensis (Bong.) Carr.). Plant Cell Reports 7: 594-597.

Lacour, L. 1941. Acetic-orcein. A new stain fixative for chromosomes. Stain Tech, 16:123.

Lelu, M.-A., Boulay, M. and Arnaud, Y. 1987. Obtention de cals embryogènes à partir de cotyledons de Picea abies (L.) Karst. prélevés sur de jeunes plantes âgées de 3 à 7 jours après germination. C. R. Acad. Sci. Paris série III t. 305: 105-109.

Lu, C.-Y. and Thorpe, T. A. 1987. Somatic embryogenesis and plantlet regeneration in cultured immature embryos of Picea glauca. J. Plant Physiol. 128: 297-302.

Murashige, T. and Skoog, F. 1962. A revised medium for rapid growth and bioassays with tobacco tissue culture. Physiol. Plant. 15: 473-497.

Schuller, A., Reuther, G. and Geier, T. 1989. Somatic embryogenesis from seed explants of Abies alba. Plant Cell Tissue Org. Culture 17:53-58.

Villalobos, V. M., Yeung, E. C. and Thorpe, T. A. 1985. Origin of adventitious shoots in excised radiata pine cotyledons cultured in vitro. Can. J. Bot. 63: 2172-2176.

von Arnold, S. 1987. Improved efficiency of somatic cmbryogencsis in mature cmbryos of Picea abies (L.). J. Plant Physiol. 128: 233-244.

von Arnold, S. and Eriksson, T. 1979a. Induction of adventitious buds on buds of Norway spruce (Picea abies) grown in vitro. Physiol. Plant. 45: 29-34.

- $1979 \mathrm{~b}$. Bud induction on isolated needles of Norway spruce (Picea abies L., Karst.) grown in vitro. Plant Sci. Letters 15: 363-372.

von Arnold, S. and Hakman, I. 1986. Effect of sucrose on initiation of embryogenic callus cultures from mature zygotic embryos of Picea abies. (L.) Karst. (Norway spruce). J. Plant Physiol. 122: 261-265.

von Arnold, S. and Woodward, S. 1988. Organogenesis and embryogenesis in mature zygotic embryos of Picea sitchensis. Tree Physiology 4: 291-300.

Yeung, E. C., Aitken, J., Biondi, S. and Thorpe, T. A. 1981. Shoot histogenesis in cotyledon explants of radiata pine. Bot. Gaz. 142: 494-501. 